\title{
Monitoring Dan Evaluasi Penerapan Sistem Tanam Jajar Legowo Pada Usaha Tani Padi Sawah Di Desa Cermin Alam Kecamatan Vii Koto Ilir Kabupaten Tebo
}

\author{
Suyatno $^{1}$, H. Syaiful Azhar ${ }^{2}$, dan Asminar ${ }^{3}$ \\ ${ }^{1}$ Alumni Program Studi Agribisnis Fakultas Pertanian UMB \\ ${ }^{2}$ Program Studi Agribisnis Fakultas Pertanian UMB \\ asminarjabir@yahoo.co.id
}

\begin{abstract}
ABSTRAK
Penelitian ini dilaksanakan di Desa Cermin Alam Kecamatan VII Koto Ilir Kabupaten Tebo yang dimulai dari tanggal 15 April 2015 sampai dengan 15 Mei 2015 di Desa Cermin Alam Kecamatan VII Koto Ilir Kabupaten Tebo yang terdapat petani yang mengupayakan usaha tani padi jajar legowo.

Penelitian ini dilakukan bertujuan untuk mengetahui perkembangan penerapan sistem legowo, untuk mengetahui penerapan sistem jajar legowo, untuk mengetahui masalah-masalah yang dihadapi petani, upaya apa saja yang dilakukan untuk menghadapi masalah-masalah petani di Desa Cermin Alam Kecamatan VII Koto Ilir Kabupaten Tebo.

Metode yang digunakan dalam pengambilan data adalah metode survei dengan tehnik wawancara kepada para petani berdasarkan kuisioner yang berisikan suatu rangkaian pertanyaan mengenai usahatani padi dengan sistem jajar legowo di Desa Cermin Alam Kecamatan VII Koto Ilir Kabupaten Tebo dan pengambilan data dilakukan secara sensus secara acak dengan 37 petani.

Penerapan sistem jajar legowo tipe cara tanam sistem jajar legowo secara umum dapat dilakukan yaitu : tipe legowo (2:1), (3:1), (4:1), (5:1). Penerapan sistem jajar legowo dinyatakan berhasil, permasalahan jajar legowo memiliki jarak tanam dalam baris tidak sama dengan antar baris, minimnya sosialisasi petani sulit untuk mendapatkan informasi jajar legowo, irigasi yang tidak memadai, biaya untuk upah tanam lebih tinggi. Upaya diciptakan tali pembantu yang telah dibuat jaraknya sesuai dengan jarak tanam, pertemuan kelompok diskusi dan praktek langsung, secara gotong royong perbaikan saluran irigasi kelahan-lahan petani, menggunakan tenaga kerja dalam keluarga.
\end{abstract}

Kata Kunci : Monitoring, Evaluasi, dan Sistem Tanam Legowo

\section{PENDAHULUAN}

Sektor pertanian sangat berpengaruh dalam pembentukan PDRB (Produk Domestik Regional Bruto), dimana kontribusinya dalam pembentukan PDRB Provinsi Jambi Tahun 2013 sebesar 29,69 \% dari total PDRB Provinsi Jambi. Sedangkan untuk subsektor tanaman bahan makanan sendiri kontribusinya terhadap PDRB Provinsi Jambi Tahun 2013 sebesar 8,63\%. Saat ini pemerintah telah berupaya meningkatkan pemanfaatan lahan dengan pencetakan sawah baru, intensifikasi dan menghimbau untuk diversifikasi pangan. Hal ini dilakukan agar ketahanan semakin kuat, terutama di Provinsi Jambi. (BPTP, 2015).

Prinsip dari sistem tanam jajar legowo adalah meningkatkan populasi tanaman dengan mengatur jarak tanam sehingga pertanaman akan memiliki barisan tanaman yang diselingi oleh barisan kosong dimana jarak tanam pada barisan pinggir setengah kali jarak tanam antar barisan. Sistem tanam jajar legowo merupakan salah satu rekomendasi yang terdapat dalam paket anjuran Pengelolaan Tanaman Terpadu (PTT) (Sembiring, 2001).

Sistem tanam jajar legowo juga merupakan suatu upaya memanipulasi lokasi pertanaman sehingga pertanaman akan memiliki jumlah tanaman pingir yang lebih banyak dengan adanya barisan kosong. Seperti diketahui bahwa tanaman padi yang berada dipinggir memiliki pertumbuhan dan perkembangan yang lebih baik dibanding tanaman padi yang berada di barisan tengah sehingga memberikan hasil produksi dan kualitas gabah yang lebih tinggi. Hal ini disebabkan karena tanaman yang berada dipinggir akan memperoleh intensitas sinar matahari yang lebih banyak (efek tanaman pinggir).

Menurut balai penelitian tanaman pangan (2015), sistem tanam jajar legowo sangat bagus diterapkan di Provinsi Jambi. Hal ini disebabkan karena hasil produksi padi di Provinsi Jambi 


\section{Jurnal Agri Sains Vol, 1 No.02 (2017)}

mengalami penurunan dari tahun 2011 - 2013 sebanyak 71.730 Ton, hal ini disebabkan karena kurangnya inovasi, teknologi, dan informasi tentang peningkatan produksi padi sawah. Oleh sebab itu produktivitas padi menurun akibat kurangnya wawasan dan berita mengenai padi sawah, dengan adanya evaluasi ini hasil produksi padi diharapkan dapat meningkat (BPTP, 2015).

Masyarakat pada umumnya dengan menanam padi dengan jarak yang sempit maka hasil akan banyak, anggapan serta opini petani kita dalam menerapkan pola tanam khususnya pengaturan jarak tanam saat ini cenderung salah yaitu menganggap bahwa semakin sempit jarak tanam maka hasil akan semakin banyak karena akan semakin banyak populasi tanaman yang ditanam. Untuk menangani rendahnya produktivitas pertanian saat ini, maka perlu suatu teknologi dan inovasi dalam meningkatkan produksi pertanian khususnya masalah jarak tanam, oleh karena itu diperlukan inovasi baru yang dapat mendongkrak dan mensejahterakan para petani padi dengan menggunakan teknologi legowo, dengan adanya teknologi baru yang dimanfaatkan oleh para petani diharapkan mempunyai pendapatan yang lebih dengan adanya teknologi legowo.

Menurut Dinas Pertanian Dan Tanaman Pangan Kabupaten Tebo (2015) Kabupaten yang ada di Provinsi Jambi mempunyai prospek untuk pengembangan jajar legowo adalah Kabupaten Tebo. Hal inipun didukung dengan program swasembada pangan. Kabupaten Tebo terdiri dari 12 Kecamatan, dari 12 kecamatan tersebut hanya 9 kecamatan yang mengelola budidaya padi dan dari semua Kecamatan yang produktivitas padi paling banyak ialah Kecamatan VII Koto Ilir yang memiliki 4,97 Ton/Ha, dengan adanya hasil produktivitas terbanyak ternyata di kecamatan VII Koto Ilir telah menggunakan teknologi legowo sekitar 3 tahun. Inspirasi yang luar biasa yang telah didongkrak dengan adanya teknologi legowo diharapkan para petani padi sawah yang menggunakan teknologi legowo ini mampu mensejahterakan keluarganya dan masyarakat yang menikmati padi hasil teknologi legowo ini (Dinas Pertanian Dan Tanaman Pangan Kabupaten Tebo, 2015)

Bedasarkan uraian diatas maka perlu melakukan penelitian tentang "Monitoring Dan Evaluasi Penerapan Teknologi Legowo Pada Usaha Tani Padi Sawah Dikecamatan VII Koto Ilir Kabupaten Tebo“. Adapun tujuan Penelitian ini adalah untuk mengetahui penerapan pengembangan teknologi jajar legowo pada usahatani padi sawah dan untuk mengetahui masalah - masalah yang dihadapi petani saat penerapan teknologi legowo serta upaya apa saja yang dilakukan untuk menghadapi masalah masalah petani saat penerapan teknologi legowo.

\section{METODOLOGI PENELITIAN}

Metode penentuan daerah penelitian ini dilaksanakan di Desa Cermin Alam Kecamatan VII Koto Ilir Kabupaten Tebo atas pertimbangan bahwa daerah ini memiliki produktivitas padi yang paling banyak 4,97 Ton/Ha, dengan mengunakan teknologi legowo dan perencanaan swasembada beras di Kabupaten Tebo. Dengan peningkatan produksi maka di Kecamatan VII Koto Ilir akan dijadikan sebagai contoh daerah yang sukses dengan hasil produksi berasnya, dapat dibandingkan dengan daerah lain Di Kabupaten Tebo (Dinas Pertanian Dan Tanaman Pangan Kabupaten Tebo, 2016).

Adapun jenis data yang digunakan dalam penelitian ini adalah data primer dan data sekunder. Data primer dalam penelitian ini diperoleh secara langsung dengan petani sampel yang dipandu oleh daftar pertanyaan (kuisioner) yang telah disiapkan terlebih dahulu. Sedangkan data sekunder diperoleh dari dinas atau instansi terkait dan sumber - sumber lain, serta litelatur yang berhubungan dengan penelitian ini.

Metode penelitian yang digunakan adalah survei. Menurut Nazir (2003), metode survei adalah salah satu metode pengumpulan data yang dilakukan untuk memperoleh fakta dari gejala yang ada dan mencari keterangan-keterangan secara faktual, baik tentang institusi sosial, ekonomi, atau politik dari suatu kelompok maupun daerah. Survei bertujuan untuk mengkaji masalah sehingga mendapatkan pembenaran atas masalah yang dihadapi, sehingga hasilnya dapat digunakan untuk membuat perencanaan dan pengambilan keputusan di masa mendatang. Penelitian ini dilakukan dengan menggunakan sampel, artinya tidak semua individu dalam populasi digunakan sebagai responden, melainkan hanya sebagian saja yang hasilnya diharapkan dapat menjelaskan sifat populasi secara keseluruhan. Metode penelitian ini dipilih karena dianggap paling sesuai dengan permasalahan di Desa Cermin Alam Kecamatan VII Koto Ilir.

Penentuan petani sampel dilakukan secara simple random sampling, populasi yang bersangkutan diambil secara acak dengan mengambil sampel sebanyak 30\% dari Desa Cermin Alam karena hanya Desa Cermin Alam yang menggunakan teknologi legowo di Kecamatan Vll Koto Ilir (BPP Kecamatan 


\section{Jurnal Agri Sains Vol, 1 No.02 (2017)}

V11 Koto Ilir, 2015). Kondisi ini sejalan dengan pernyataan singarimbun dan effendi (1982) dengan mengatakan bahwa besarnya sampel (sample size) yang harus diambil untuk mendapatkan data yang representatif minimal 5\%. Hal ini didasarkan pada kondisi lapangan yang relative homogen dan dapat mewakili populasi. Homogen disini merupakan petani yang mengusahakan padi jajar legowo di Desa Cermin Alam dengan populasi KK 121 petani dan sampel 30 $\%$ berjumlah 37 petani.

Data yang diperoleh dari penelitian dikumpulkan dan diolah secara tabulasi kemudian dianalisis secara deskriptif.

1. Identifikasi masalah penerapan jajar legowo pada usaha tani padi sawah dianalisis secara deskriptif dengan menghitung penerapan PTT pada petani sampel dengan teknologi legowo.

2. Identifikasi masalah perkembangan penerapan teknologi legowo didaerah penelitian dianalisis secara deskriptif dan menjelaskan pertambahan luas lahan usaha tani legowo yang diterapkan didaerah penelitian.
3. Identifikasi masalah - masalah yang dihadapi petani dalam penerapan legowo dianalisis secara deskriptif dengan menjelaskan masalah apa saja yang dihadapi petani dalam penerapan teknologi legowo.

4. Identifikasi upaya yang di lakukan untuk menghadapi masalah - masalah yang dihadapi petani dalam penerapan legowo dianalisis secara deskriptif dengan menjelaskan masalah apa saja yang dihadapi petani dalam penerapan teknologi legowo.

\section{HASIL DAN PEMBAHASAN}

Petani Sampel Yang Mengusahakan Jajar Legowo Di Daerah Penelitian

Petani sampel yang mengusahakan usahatani padi dengan menggunakan sistem jajar legowo untuk melihat sistem jajar legowo yang diterapkan di Desa Cermin Alam Kecamatan VII Koto Ilir Kabupaten Tebo.

Tabel 1. Petani Sampel Yang Mengusahakan Jajar Legowo

\begin{tabular}{|c|c|c|c|}
\hline No & Jajar Legowo & Petani Sampel & \% \\
\hline 1 & $2: 1$ & 18 & 48,65 \\
\hline 2 & $3: 1$ & 8 & 21,62 \\
\hline 3 & $4: 1$ & 8 & 21,62 \\
\hline 4 & $5: 1$ & 3 & 8,11 \\
\hline & & $\mathbf{3 7}$ & $\mathbf{1 0 0}$ \\
\hline
\end{tabular}

Sumber : Data primer diolah, 2015

Tabel 1 menunjukkan bahwa untuk mengetahui dari petani yang dijadikan sampel yang mengusahakan padi dengan sistem jajar legowo dapat disimpulkan bahwa petani terbanyak yang menggunakan sistem jajar legowo merupakan sistem jajar legowo 2:1 dengan jumlah 18 petani sampel dengan persentase tertinggi $48,65 \%$, sedangkan yang menggunakan sistem jajar legowo terendah yaitu sitem jajar legowo 5:1 dengan jumlah 3 petani sampel dengan persentase $8,11 \%$. Hal ini menunjukkan bahwa petani berantusias dalam bertani padi menggunakan dengan sistem jajar legowo.

\section{Penerapan Jajar Legowo Pada Usaha Tani Padi Sawah Di Daerah Penelitian}

Tipe cara tanam sistem jajar legowo yang secara umum dapat dilakukan yaitu tipe legowo (2:1), (3:1), (4:1), (5:1), dan tipe lainnya yang sudah ada serta telah diaplikasikan oleh sebagian masyarakat petani di Indonesia. Namun berdasarkan penelitian yang dilakukan di Balai Pengkajian Teknologi
Pertanian diketahui jika tipe sistem tanam jajar legowo terbaik dalam memberikan hasil produksi gabah tinggi adalah tipe jajar legowo (4:1) sedangkan dari tipe jajar legowo $(2: 1)$ dapat diterapkan untuk mendapatkan bulir gabah berkualitas benih.

1. Jajar Legowo (2:1)

Penerapan sistem jajar legowo (2:1) dapat meningkatkan produksi padi dengan gabah kualitas benih dimana sistem jajar legowo seperti ini sering dijumpai pada pertanaman untuk tujuan penangkaran atau produksi benih. Untuk lebih jelasnya tentang cara tanam jajar legowo (2:1) dapat dilihat melalui gambar di bawah ini. Desa Cermin Alam Kecamatan VII Koto Ilir Kabupaten Tebo dari petani sampel paling banyak menggunakan penerapan sistem jajar legowo 2:1 karena cara penanaman yang tidak terlalu banyak membuat tali barisan akan mempermudah petani dalam upaya membuat sistem jajar legowo 2:1, membuat tali barisan diatas lumpur dengan peralatan 


\section{Jurnal Agri Sains Vol, 1 No.02 (2017)}

seadanya itu tidak mudah, jarak yang agak jauh membuat tali susah untuk dikencangkan.

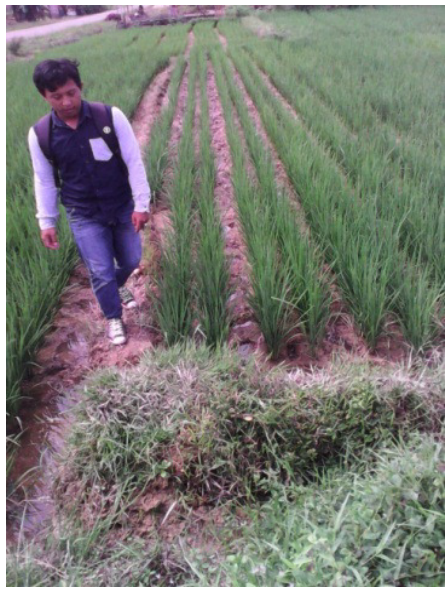

\section{Jajar Legowo (3:1)}

Jajar legowo (3:1) adalah cara tanam padi dimana setiap tiga baris tanaman diselingi oleh satu barisan kosong yang memiliki jarak dua kali dari jarak tanaman antar barisan. Modifikasi tanaman pinggir dilakukan pada baris tanaman ke-1 dan ke-3 yang diharapkan dapat diperoleh hasil tinggi dari adanya efek tanaman pinggir. Prinsip penambahan jumlah populasi tanaman dilakukan dengan cara menanam pada setiap barisan pinggir (baris ke-1 dan ke-3) dengan jarak tanam setengah dari jarak tanam antar barisan. Dengan demikian jarak tanam pada sistem jajar legowo (3:1) adalah $20 \mathrm{~cm}$ (antar barisan dan pada barisan tengah) X $10 \mathrm{~cm}$ (barisan pinggir) $\mathrm{X} 40$ $\mathrm{cm}$ (barisan kosong).

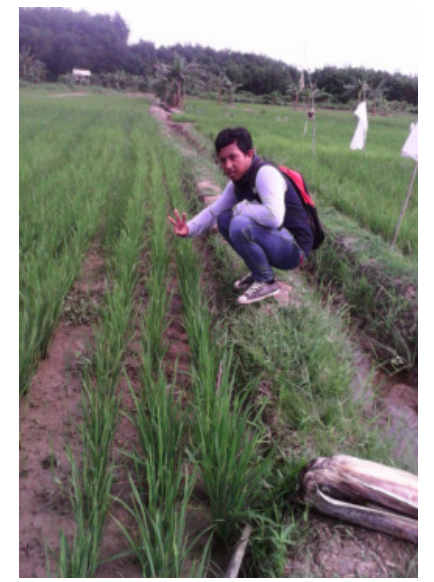

\section{Jajar Legowo (4:1)}

Jajar legowo (4:1) adalah cara tanam padi dimana setiap empat baris tanaman diselingi oleh satu barisan kosong yang memiliki jarak dua kali dari jarak tanaman antar barisan. Sistem legowo seperti ini maka setiap baris tanaman ke-1 dan ke-4 akan termodifikasi menjadi tanaman pinggir yang diharapkan dapat diperoleh hasil tinggi dari adanya efek tanaman pinggir. Prinsip penambahan jumlah populasi tanaman dilakukan dengan cara menanam pada setiap barisan pinggir (baris ke-1 dan ke-4) dengan jarak tanam setengah dari jarak tanam antar barisan. Dengan demikian jarak tanam pada sistem jajar legowo (4:1) adalah $20 \mathrm{~cm}$ (antar barisan dan pada barisan tengah) $\mathrm{X} 10 \mathrm{~cm}$ (barisan pinggir) X $40 \mathrm{~cm}$ (barisan kosong).

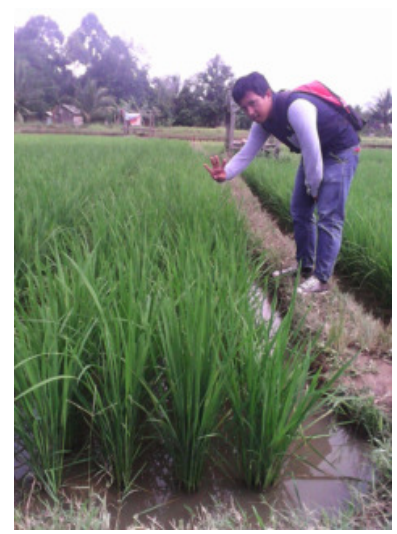

\section{Jajar Legowo (5:1)}

Jajar legowo (5:1) adalah cara tanam padi dimana setiap lima baris tanaman diselingi oleh satu barisan kosong yang memiliki jarak dua kali dari jarak tanaman antar barisan. Dengan sistem legowo seperti ini maka setiap baris tanaman ke-1 dan ke-5 akan termodifikasi menjadi tanaman pinggir yang diharapkan dapat diperoleh hasil tinggi dari adanya efek tanaman pinggir. Prinsip penambahan jumlah populasi tanaman dilakukan dengan cara menanam pada setiap barisan pinggir (baris ke-1 dan ke-5) dengan jarak tanam setengah dari jarak tanam antar barisan. Dengan demikian jarak tanam pada sistem jajar legowo (5:1) adalah $20 \mathrm{~cm}$ (antar barisan dan pada barisan tengah) X $10 \mathrm{~cm}$ (barisan pinggir) $\mathrm{X} 40$ $\mathrm{cm}$ (barisan kosong).

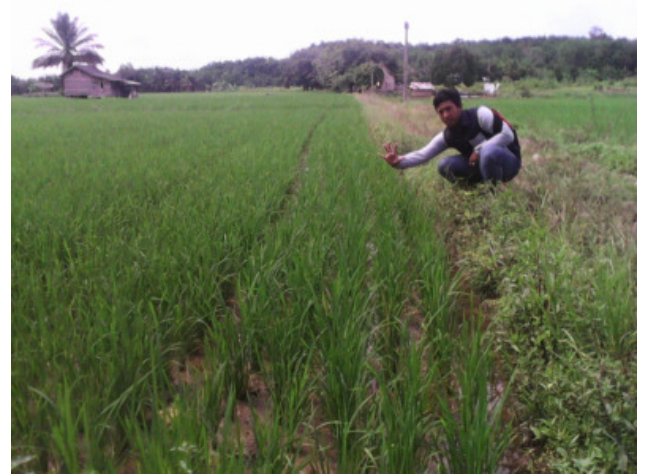


Perkembangan Penerapan Jajar Legowo Di Daerah Penelitian

Perkembangan penerapan jajar legowo dapat dilihat dari perkembangan luas lahan, apabila luas lahan mengalami penambahan dari tahun 2009 - 2015 maka luas lahan tersebut mengalami perkembangan, perkembangan luas lahan jajar legowo yang diusahakan petani dapat dilihat dibawah ini:

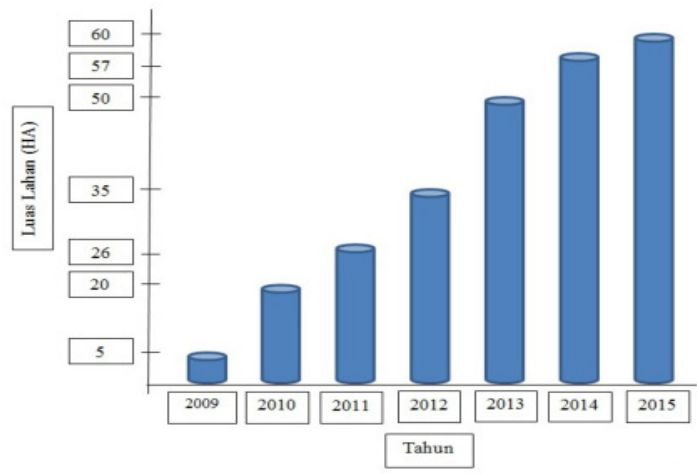

Gambar 1. Perkembangan Penerapan Jajar Legowo (Balai Penyuluhan Pertanian Kecamatan VII Koto Ilir, 2016)

Gambar 1 menunjukkan bahwa dari setiap tahunnya mengalami peningkatan, peningkatan terbanyak yaitu dari tahun 2009 dengan luas lahan 5 hektar ke tahun 2010 dengan luas 20 hektar mengalami peningkatan 15 hektar, sama dengan tahun 2012 dengan luas 35 hektar ke tahun 2013 dengan luas 50 hektar mengalami peningkatan 15 hektar, sedangkan peningkatan yang paling sedikit ditahun 2014 dengan luas 57 hektar ke tahun 2015 dengan luas 60 hektar mengalami peningkatan 3 hektar, hal ini disebabkan lahan persawahan untuk padi jajar legowo sudah diusahakan semua oleh petani dengan cara jajar legowo, karena kemungkinan yang di upayakan sudah tinggal pemukiman penduduk, perkebunan karet.

\section{Permasalahan Yang Dilakukan Untuk Menghadapi Masalah Penerapan Teknologi Legowo}

\section{Permasalahan dalam Replikasi PTT} (Pengelolaan Tanaman Terpadu)

Bagian tersulit dalam memperkenalkan konsep PTT adalah metode determinasi agar berbagai pihak dapat memahami manfaat intensifikasi padi menggunakan PTT. Laporan tim peneliti perwakilan IRRI (International Rice Research Institute) di Indonesia menunjukkan rendahnya pengetahuan dan pemahaman petani dalam menggunakan BWD (Bagan Warna Daun) di lokasi yang semula dijadikan wilayah demonstrasi PTT (Sembiring dan Abdulrachman,
2008). Hal serupa juga ditemukan di Pangkep dan Bone, dimana petani peserta PTT di daerah ini tidak menerapkan komponen teknologi BWD dengan alasan ketiadaan alat (Limbongan et al. 2011). Hal ini menggambarkan bahwa pemahaman PTT masih berada di tingkat permukaan (pemahaman dasar). Diperlukan pemahaman mendasar tentang konsep PTT oleh peneliti, penyuluh, petugas dinas pertanian, dan petani untuk menunjang keberhasilan pelaksanan PTT.

\section{Permasalahan Yang Dihadapi Petani}

Menurut petani diungkapan bahwa ada beberapa kendala dalam penerapan sistem tanam jajar legowo, diantaranya adalah:

a. Sistem tanam dalam baris tidak sama dengan antar baris.

Jarak tanam jajar legowo yang diusahakan oleh petani dalam baris lebih sempit dibandingkan antara baris, untuk baris penanaman sistem jajar legowo yang ditanami sekitar $10 \mathrm{~cm}$, sedangkan untuk antara barisan (barisan kosong) sekitar 20 cm. Dalam sistem penanaman jajar legowo membutuhkan waktu yang tidak sebentar, mengukur jarak yang akan ditanam, memasang tali pembantu agar terbantu dalam menerapkan antar baris, dan harus benar-benar memperhatikan tali pembantu agar tanaman lurus dan tidak memakan tempat.

b. Jadwal berkumpul petani.

Minimnya waktu petani sulit untuk mendapatkan informasi penunjang untuk bertani padi sistem jajar legowo, dikarenakan jadwal petani yang memiliki kesibukan berkebun dan sebagainya.

c. Hama dan penyakit.

Hama dan penyakit adalah pengganggu yang tidak bisa dijauhkan dari tanaman padi, selain hama seperti tumbuhan pengganggu, burung, tikus, penggerek, keong, dan pengganggu lainnya, ada juga penyakit seperti batang mengkuning saat masih muda, bercak-bercak pada daun, tangkai membusuk, dan lain sebagainya.

d. Irigasi yang tidak memadai.

Cuaca yang tidak menentu tentu saja akan membuat petani pusing dalam mengatasi kemarau panjang, air sulit untuk untuk didapat hal ini berpengaruh dalam produksi padi.

e. Pupuk dan pemupukan.

Keadaan yang sedang krisis membuat petani semakin kesusahan dalam membeli pupuk dan mengaplikasikan pemupukan guna memberi 
nutrisi pada padi yang diusahakan. Petani mengharapkan keadaan perekonomian dapat mengimbangi kebutuhan rumah tangga sekaligus dalam membeli pupuk, bagi petani yang memiliki sawah kurang dari $500 \mathrm{~m}^{2}$ sulit untuk memenuhi kebutuhan hidup dan membeli pupuk.

f. biaya pemanenan tinggi.

Biaya untuk upah tanam lebih tinggi tanam jajar legowo deengan biaya Rp 750.000,- s/d Rp 800.000,- per hektar tergantung tipe legowonya. Hal ini disebabkan adanya cara penanamannya dalam sistem berbeda antar baris.

Upaya Yang Dilakukan Untuk Menghadapi Masalah Penarapan Teknologi Legowo

1. Upaya Yang Dilakukan Dalam Replikasi PTT (Pengelolaan Tanaman Terpadu)

Upaya pemasyarakatan PTT memerlukan dukungan dari berbagai pihak terkait, terutama pemerintah daerah. Konsep PTT dipahami sebagai program bersama antara Pemerintah Pusat dan Daerah dalam upaya untuk menunjang produksi padi nasional dan pendapatan petani, di era otonomi daerah ini diperlukan keterlibatan yang lebih besar lagi dari pemerintah provinsi sebagai wakil pemerintah pusat, serta kabupaten/kota sebagai penanggung jawab pada tingkat kabupaten/kota serta lapangan. Seyogianya pemerintah daerah berkewajiban menyediakan dana pendamping untuk membiayai program peningkatan pengetahuan petani dalam bidang pertanian.

Permasalahan lain dalam replikasi PTT antara lain adanya kendala antarsektoral dalam peningkatan produksi karena berbagai perubahan lingkungan strategis di luar sektor pertanian, selain itu berkurangnya ketersediaan lahan akibat alih fungsi lahan, berkurangnya ketersediaan air irigasi karena sumber - sumber air semakin berkurang dan persaingan menggunakan air di luar sektor pertanian, meningkatnya harga sarana produksi, BBM, dan upah tenaga kerja serta laju pertumbuhan penduduk. Kesamaan tujuan dari berbagai stakeholders perlu dibangun atas dasar saling memerlukan. Stakeholders yang dimaksud adalah setiap personel dan unit kerja yang terlibat dalam proses agribisnis, yang terdiri atas petani (kelompok tani), peneliti, penyuluh pertanian (BPTP, Dinas Pertanian) serta pengusaha (pemasok saprodi, SHS/ Pertani, PUSRI/pengusaha pupuk, pengusaha pestisida, pedagang, eksportir). Petani atau kelompok tani bertindak sebagai pelaksana usahatani dengan penerapan teknologi spesifik lokasi yang sudah teruji. Peneliti dan penyuluh BPTP memasok teknologi spesifik lokasi dan membimbing penerapannya di lapangan. Penerapan teknologi diawasi bersama oleh aparat Dinas Pertanian dan BPTP melalui temu lapang atau temu diskusi, yang diterapkan minimal dua kali dalam satu musim tanam. Di samping itu, penyuluh BPTP dan penyuluh Dinas Pertanian bertugas menjembatani antara petani dengan pengusaha. Pengusaha memasok semua sarana produksi yang dibutuhkan dalam proses produksi, semua sarana produksi dibayar pada saat panen, tetapi sebelumnya telah disepakati mengenai harga sarana produksi dan harga gabah serta sistem pembayaran.

\section{Upaya Yang Dilakukan Untuk Petani}

Upaya - upaya yang dilakukan dalam menghadapi masalah petani dalam penerapannya, baik masalah teknis yang dihadapi petani :

1. Dalam baris tanam lebih sempit dibanding sela (jarak barisan kosong).

Untuk mengatasi jarak tanam maka telah diciptakan tali pembantu yang telah dibuat jaraknya sesuai dengan jarak tanam.

2. Minimnya waktu petani.

Pertemuan kelompok diskusi dan praktek langsung adalah metode yang digunakan agar petani terbiasa dengan menerapkan teknologi legowo, pertemuan kelompok dan diskusi dilakukan untuk membahas masalah - masalah yang dihadapi dilapangan, sedangkan praktek langsung dilakukan agar petani mampu dan terbiasa dalam menerapkan teknologi legowo.

3. Hama dan penyakit.

Hama dan penyakit biasanya ditanggulangi petani langsung turun kesawah dengan perawatan langsung baik menggunakan alat seperti memakai bunyi - bunyian kaleng untuk mengusir burung, buat orang - orangan sawah, memakai sabit untuk memotong tanaman pengganggu, serta menggunakan obat - obatan, sebagian bagi orang mampu selain mengerjakan dengan buruh, ditambah pula dengan pengaplikasian herbisida dan insektisida berkelanjutan.

4. Irigasi yang tidak memadai.

Untuk masalah irigasi karena teknologi legowo menghendaki pengairan secara intermittent (curah hujan yang tidak pasti) maka dilakukan gotong royong perbaikan saluran irigasi kelahan - lahan petani dan mengusahakan proposal kepihak terkait.

5. pupuk dan pemupukan.

Cara menanggulangi masalah pupuk dan pemupukan yaitu dengan cara petani beternak yang bisa berhubungan timbal balik dengan tanaman budidaya padi. Limbah ternaknya 


\section{Jurnal Agri Sains Vol, 1 No.02 (2017)}

dikomposkan menjadi pupuk, sedangkan limbah pertaniannya bisa dijadikan pakan ternak. Cara ini mengurangi beban petani dalam pemupukan, serta mengurani beban pakan untuk ternak.

6. Masalah biaya untuk upah tanam lebih tinggi.

Sedangkan untuk masalah tenaga tanam biasanya menggunakan tenaka kerja dalam keluarga.

\section{Kesimpulan}

\section{KESIMPULAN DAN SARAN}

1. Berdasarkan hasil penelitian penerapan teknologi legowo tipe cara tanam sistem jajar legowo yang secara umum dapat dilakukan yaitu ; tipe legowo (2:1), (3:1), (4:1), (5:1), yang sesuai dengan anjuran Pengelolaan Tanaman Terpadu.

2. Perkembangan penerapan teknologi legowo dapat dilihat berdasarkan luas lahan, dengan berkembangnya luas lahan maka penerapan teknologi legowo mengalami kemajuan dan dapat dikatakan bahwa penerapan teknologi legowo dinyatakan berhasil.

3. Permasalahan Yang Dihadapi Petani Saat Penerapan Teknologi Legowo

a) Sistem tanam dalam baris tidak sama dengan antar baris.

b) Jadwal berkumpul petani.

c) Menanggulangi hama dan penyakit.

d) Irigasi yang tidak memadai.

e) Pupuk dan pemupukan.

f) Biaya untuk upah tanam lebih tinggi.

4. Upaya Yang Dihadapi Petani Saat Penerapan Teknologi Legowo

a) Diciptakan tali pembatu yang telah dibuat jaraknya sesuai dengan jarak tanam.

b) Pertemuan kelompok diskusi dan praktek langsung.

c) Melakukan perawatan menggunakan alat dan menggunakan obat-obatan.

d) Secara gotong royong perbaikan saluran irigasi kelahan-lahan petani.

e) Limbah ternak dikomposkan menjadi pupuk.

f) Menggunakan tenaga kerja dalamkeluarga.

\section{Saran}

Teknologi legowo merupakan teknologi yang berada pada tahap awal penerapan pengenalan suatu teknologi baru maka disarankan untuk memperhatikan faktor internal dan eksternal responden, demikian juga inovasi yang disodorkan ke responden jangan dipusatkan hanya pada aspek tunggal (produksi/target) tanpa memperhatikan faktor responden sebagai pelaku usaha tani. Dalam upaya penyuluhan teknologi secara optimal penyuluh pertanian harus mampu membimbing responden dalam teknologi legowo yang tepat, agar responden terbantu dalam monitoring dan mendapatkan hasil yang maksimal dalam penerapan teknologi legowo.

\section{DAFTAR PUSTAKA}

Anonim, 1981. Dasar-Dasar Pembinaan Kelompok Tani Dalam Intensifikasi Tanaman Pangan, Satuan Pengendali Bimas, Jakarta.

Azwir. 2008. Sistem Tanam Legowo dan Pemberian P-Stater pada Padi Sawah Dataran Tinggi. Jurnal Akta Agrosia Vol. 11 No.2.

Balai Pengkajian Teknologi Pertanian, 2015. Lima Tahun Penelitian dan Pengembangan Pertanian. Gaya Teknik Offset. Bogor.

Gittinger. P.j, 1986. Analisa Ekonomi Proyek-proyek Pertanian. UI-Press. Jakarta.

Gunawan.S, 2001. Menuju Swasembada Pangan Revolusi Hijau- II : Introduksi Manajemen Dalam Pertanian. RBI. Jakarta.

Hernanto.F. 1993. Ilmu Usaha Tani. Penebar Swadaya. Jakarta.

Hernanto. 1996. Ilmu Usahatani. Penebar Swadaya. Yogyakarta.

Kasmir dan Jakfar. 2003. Studi Kelayakan Bisnis. Prenada Media. Jakarta.

Kementrian Pertanian. 2011. Petunjuk Teknis Pengawasan Pupuk dan Pestisida Tahun 2011.

Pujaratno, B. 2010. Tanam Padi Sistem Jajar Legowo. www.google.com. Situmorang dan Dilham. 2007. Studi Kelayakan Bisnis. USU Press. Medan.

Sa'id.G.E.dkk, 2001. Manajemen Teknologi Agribisnis. Ghalia Indonesia. Bogor.

Sa'id. G. E. dan Harizt Intan. 2001. Manajemen Agribisnis. Ghalia Indonesia. Bogor. 


\section{Jurnal Agri Sains Vol, 1 No.02 (2017)}

Soekartawi. 1987. Prinsip Dasar Ekonomi Pertanian. Teori dan Aplikasi. Edisi Revisi. Raja Grafindo Persada. Jakarta

Soekartawi. 1995. Analisis Usaha Tani. UI-Press. Jakarta.

Simatupang dkk, 1997. Prosiding Agribisnis "Dinamika Sumberdaya dan Pengembangan Sistem Usaha Pertanian. Departemen Pertanian. Jakarta.

Suhartini. 2010. Modul Perkuliahan III Produksi (Teori, Fungsi, dan Efisiensi). Fakultas Pertanian Universitas Brawijaya. Malang

Suhendrata, Tota. 2008. Peran Inovasi Teknologi Pertanian Dalam Peningkatan Produktivitas Padi Sawah Untuk Mendukung Ketahanan Pangan. Prosiding Seminar Nasianal Teknik Pertanian 2008
Suryana.A, 2007. Produksi Benih Sumber Padi. Badan Penelitian dan Pengembangan Teknologi. Sumatera Utara.

Suyamto, 2007. Teknologi Unggulan Tanaman Pangan. Badan Penelitian dan Pengembangan Teknologi. Bogor.

Taher.A, 2000. Teknologi Shaffer Pada Padi Sawah. Badan Penelitian dan Pengembangan Teknologi Sukarami. Sumatera Barat.

Van den Ban, A.W. dan H.S. Hawkins. 1999. Penyuluhan Pertanian. Kanisius. Yogyakarta.

http://www.informasipertanian.com/2013/07/tanampadi-dengan-sistem-jajar-legowo.html http://kbunq.blogspot.com/2013/07/cara-menanampadi-sawah-cara-bertanam.html https://sekarmadjapahit.wordpress.com/2012/01/3 0/tanam-padi-sistem-jajar-legowo/ 